\title{
Synthesis and Characterization of New 1,2-Dihydropyridine-3-Carbonitrile Compounds with Study of Expected Biological Activity
}

\author{
Hiba H.Ibraheem ${ }^{1 *}$, Yasameen K. Al-Majedy ${ }^{1}$, Ali J.Salim ${ }^{2}$ and Redha I. Al-Bayati ${ }^{2}$. \\ ${ }^{1}$ Chemistry division, Department of applied science, University of Technology, Baghdad-Iraq. \\ ${ }^{2}$ Department of Chemistry, College of Science, Al-Mustansiriya University, Baghdad-Iraq. \\ *Corresponding Author: dr.hiba1982@gmail.com.
}

\begin{abstract}
New 1,2-dihydropyridine-3-carbonitrile derivative compounds $(3,4)$ were synthesized by cyclization of ketones (compound (1) and compound (2)) with appropriate aldehydes (4-N, Ndimethylaminobenzaldehyde and 4-chloro-2-oxo-2H-chromene-3-carbaldehyde) in presence of ethyl cyano acetate and ammonium acetate. The new synthesized compounds have been characterized using Melting point, FT-IR spectroscopy and ${ }^{1} \mathrm{H}-\mathrm{NMR}$ and ${ }^{13} \mathrm{C}-\mathrm{NMR}$ spectrum. The evaluation of biological activity of some synthesized compounds (1-4) with different concentration $10 \mathrm{mg} \mathrm{mL}^{-1}, 1 \mathrm{mg} \mathrm{mL}^{-1}$ and $0.1 \mathrm{mg} \mathrm{mL}^{-1}$, against two types of bacteria on gram positive bacterial Staphylococcus aureus, Streptococcus pyogenus and gram nagetive bacterial Escherichia coli, Klebsiella pneumniae. [DOI: $10.22401 /$ JNUS.21.2.07]
\end{abstract}

Keywords: 1, 2-Dihydropyridine, 2 H-Chromen-2-Ones.

\section{Introduction}

$2 \mathrm{H}$-chromen-2-one and its derivatives of the most serious O-heterocycles are extensively established at different bioactive natural and synthetic yields [1]. They have been efficient pharmacophores, vastly utilized for the designing and synthesis of novel bioactive compounds [2]. Accordingly, various biological activities like anticoagulation and cardiovascular activities (warfarin) [3] and antimicrobial activities (novobiocin and clorobiocin) [4] have been reported. Antioxidant anti-inflammatory [5], antibacterial - antifungal, anti-HIV, anticoagulant, antitumor, antimicrobial [6,7], Analgesic, anti-pyretic [8]. Pyridine$2(1 \mathrm{H})$-ones have been believe like serious building blocks at drug discovery as abundant natural yields as well as synthetic compounds having 2-pyridone moiety and possesses a vast kind from biological characteristics. Abundant drugs containing like a skeleton were released into the clinical world and a small further were under clinical trials at e.g., Amrinone [9]. In organization for those, Pyridone and its derivatives move a major role at various biological processes and have large chemical and pharmacological importance [10]. The synthesis of the pyridinone containing heterocyclic systems take an important site at the regality from synthetic organic chemistry, because their therapeutic and pharmacological properties [11]. They have been emerged like integral backbones of over 7000 present drugs [12]. The pyridine nucleus was an integral portion from anticancer and anti-inflammatory agents [13] else. On the anther hand, cyanopyridone and cyanopyridine derivatives have been shown for owns promising antimicrobial [14] and anticancer activities [15]. This investigation demonstrated synthesis of new 1,2-dihydropyridine-3carbonitrile compounds derived from 7hydroxy-4-methyl-2H-chromen-2-one with fully characterization, and aiming to further biochemical studies.

\section{Experimental}

\subsection{Synthesis of 4-methyl-7-(2-oxopropoxy)- 2H-chromen-2-one (1)}

A mixture of 7-hydroxy-4-methyl-2Hchromen-2-one (1.76gm.,0.01 mole), chloroacetone $(0.92 \mathrm{gm} ., 0.01$ mole $)$ and potassium carbonate $(1.38 \mathrm{gm} ., 0.01 \mathrm{~mole})$ in acetone $(20 \mathrm{ml}$.) were refluxed for $6 \mathrm{hrs}$., the reaction was monitored through TLC (hexane: ethylacetate, $7: 3$ ). The reaction mixture has been filtered off, and filtrate was concentrated and allowed to cool. The precipitated was filtered, washed with water and recrystallized from ethanol to give the titled compound [16]. Melting point: $147-149^{\circ} \mathrm{C}$, Yields: $80 \%$. The FTIR spectral data showed absorption at $\left(1735 \mathrm{~cm}^{-1}\right.$, for $\left.v C=0\right), \quad\left(1617,1556 \mathrm{~cm}^{-1}\right.$, for 
$v \mathrm{C}=\mathrm{C}, \quad$ Ar. $), \quad\left(2915,2845 \mathrm{~cm}^{-1}\right.$, for $\mathrm{vCH}$, aliphatic), $\left(1706 \mathrm{~cm}^{-1}\right.$, for $\mathrm{vC}=\mathrm{O}$, lactone), $\left(3090 \mathrm{~cm}^{-1}\right.$, for $\left.v \mathrm{Ar}-\mathrm{H}\right),\left(1135 \mathrm{~cm}^{-1}\right.$, for $\left.v \mathrm{C}-\mathrm{O}\right)$, ${ }^{1} \mathrm{H}-\mathrm{NMR}$ spectra data showed signal at $(\delta=2.0$, $3 \mathrm{H}, \mathrm{s},-\mathrm{CH}_{3}$ lactone $),\left(\delta=2.8,3 \mathrm{H}, \mathrm{s}, \mathrm{CO}-\mathrm{CH}_{3}\right)$, $\left(\delta=4.9,2 \mathrm{H}, \mathrm{CH}_{2}\right),(\delta=6.1,1 \mathrm{H}, \mathrm{s}, \mathrm{C}=\mathrm{CH}$ of lactone $),(\delta=6.8-7.6,3 \mathrm{H}, \mathrm{m}, \mathrm{Ar}-\mathrm{H})$.

\subsection{Synthesis of 4-methyl-2-oxo-2H- chromen-7-yl acetate (2)}

A solution of 7-hydroxy-4-methyl-2Hchromen-2-one (2.82 gm., 0.016 mole) and acetic anhydride (1.63 ml.,0.016 mole) is refluxed for $1.5 \mathrm{hr}$.,the progress of the reaction was monitored by TLC (hexane: ethylacetate, $\left.7: 3, \mathrm{R}_{\mathrm{f}}=0.6\right)$. The reaction mixture has been poured at ice-cold water and the separated result has been filtered off and was recrystallized for ethanol. Melting point: 150$151^{\circ} \mathrm{C}$, Yields: $91 \%$. The FTIR spectral data showed absorption at $\left(1730 \mathrm{~cm}^{-1}\right.$, for $\left.v C=O\right)$, $\left(1565,1505 \mathrm{~cm}^{-1}\right.$, for $\left.v \mathrm{C}=\mathrm{C}, \mathrm{Ar}.\right), \quad(2938$, $2832 \mathrm{~cm}^{-1}$, for $\mathrm{vCH}$, aliphatic), $\left(1707 \mathrm{~cm}^{-1}\right.$, for $v \mathrm{C}=\mathrm{O}$, lactone $),\left(3076 \mathrm{~cm}^{-1}\right.$, for $\left.v \mathrm{C}-\mathrm{H}, \mathrm{Ar}.\right)$, $\left(1133 \mathrm{~cm}^{-1}\right.$, for $\left.v \mathrm{C}-\mathrm{O}\right)$.

\subsection{General procedure for 1,2-} dihydropyridine-3-carbonitrile reaction.

A solution of ketones (0.001 mole) in ethanol (10 ml.), appropriate aldehydes (0.001 mole), ethyl cyanoacetate (0.113g., 0.001 mole), ammonium acetate (0.6g.,0.008 mole) were added [17]. The reaction mixture has been refluxed at $2 \mathrm{hrs}$. The resulting has been filtered off then washed for water, dried and recrystallized from ethanol.

2.4 Synthesis of 4-(4-(dimethylamino) phenyl)-6-((4-methyl-2-oxo-2H-chromen-7yloxy)methyl)-2-oxo-1,2-dihydropyridine-3carbonitrile (3)

Melting point: $103-105 \mathrm{~d}{ }^{0} \mathrm{C}$, Yields: $90 \%$. The FTIR spectral data showed absorption at $\left(3220 \mathrm{~cm}^{-1}\right.$, for $\left.\mathrm{vNH}\right),\left(3117 \mathrm{~cm}^{-1}\right.$, for $v \mathrm{C}-\mathrm{H}$, Ar.), $\left(1703 \mathrm{~cm}^{-1}\right.$, owing to $v \mathrm{C}=\mathrm{O}$ Lactone), $\left(1650 \mathrm{~cm}^{-1}\right.$, owing to $\mathrm{vC}=\mathrm{O}$, amide $),\left(1612 \mathrm{~cm}^{-1}\right.$, for $v \mathrm{C}=\mathrm{N}), \quad\left(1570 \mathrm{~cm}^{-1}\right.$, for $v \mathrm{C}=\mathrm{C}, \quad \mathrm{Ar}$.), (2208 $\mathrm{cm}^{-1}$, for $\left.v \mathrm{CN}\right) .{ }^{1} \mathrm{H}-\mathrm{NMR}$ spectra data showed signal at $2.4\left(\mathrm{~s}, 3 \mathrm{H}\right.$ owing to $\left.\mathrm{CH}_{3}\right)$, 3.09 (s, $6 \mathrm{H}$ owing to $\left.\mathrm{N}\left(\mathrm{CH}_{3}\right)_{2}\right), 4.2$ (s, $2 \mathrm{H}$ owing to $\left.\mathrm{CH}_{2}\right), \quad 6.8-8.1 \quad(\mathrm{~m}, 10 \mathrm{H}$ owing to (Ar- $\mathrm{H}, \mathrm{C}=\mathrm{CH}$ for lactone ring, $\mathrm{C}=\mathrm{CH}$ for pyridinone ring and $\mathrm{NH})$. The ${ }^{13} \mathrm{C}-\mathrm{NMR}$ spectra data showed signal at $14,21,30,61$, $92,110,111,112,118,118.7,119,120,131$, $132,133,134,153,154,154.6,163,163.9$ and 192.

\subsection{Synthesis of 4-(4-chloro-2-oxo-2H- chromen-3-yl)-6-(4-methyl-2-oxo-2H- chromen-7-yloxy)-2-oxo-1,2- dihydropyridine-3-carbonitrile (4)}

Melting point: up $360^{\circ} \mathrm{C}$, Yields: $90 \%$. The FTIR spectral data showed absorption at $\left(3105 \mathrm{~cm}^{-1}\right.$, for $\left.v N H\right),\left(2926 \mathrm{~cm}^{-1}\right.$, for $v C-H$, Ar.), $\left(1739 \mathrm{~cm}^{-1}\right.$, owing to $\mathrm{vC}=\mathrm{O}$ Lactone), $\left(1656 \mathrm{~cm}^{-1}\right.$, owing to $\cup \mathrm{C}=\mathrm{O}$, amide $),\left(1618 \mathrm{~cm}^{-1}\right.$, for $v C=N), \quad\left(1602 \mathrm{~cm}^{-1}\right.$, for $\left.v C=C, A r.\right)$, (2220 $\mathrm{cm}^{-1}$, for $\left.v \mathrm{CN}\right) .{ }^{1} \mathrm{H}-\mathrm{NMR}$ spectra data showed signal at $2.2\left(\mathrm{~s}, 3 \mathrm{H}, \mathrm{CH}_{3}\right), 4.4(\mathrm{~s}, 1 \mathrm{H},-\mathrm{NH}$ for lactame), $6.1(\mathrm{~s}, 1 \mathrm{H}, \mathrm{C}=\mathrm{CH}$ for pyridinone ring, $6.7(\mathrm{~s}, \quad 1 \mathrm{H}, \mathrm{C}=\mathrm{CH}$ for lactone ring), 7.4-8.9 (m,7H owing to Ar-H), 10.5 (s, $1 \mathrm{H}, \mathrm{OH}$ enol). The ${ }^{13} \mathrm{C}-\mathrm{NMR}$ spectra data showed signal at 105, 115, 116, 117, 118, 119, 120, $125,125.5,135,138,147,148,150,153,154$, 158 and 162 .

\section{Agar Diffusion Assays}

By applying the ager plat diffiusion technique [18] some of the synthesized compounds have been screend at vitro to antibacterial activity against Staphylococcus aureus and Streptococcus pyogenus (Gram +ve bacteria) and Escherichia coli and Klebsiella pneumniae (Gram-ve bacteria). Intended agar and petridishes have been sterilized through autoclaving to $(15 \mathrm{~min})$ by $121^{\circ} \mathrm{C}$. The ager plates have been surface injected uniformly for the broth culture from the tested microorganisms. At the solidified medium appropriately spaced away holes have been made all $(6 \mathrm{~mm})$ at diameter, have been filled with $100 \mu \mathrm{l}$ from the prepared compounds.

The synthesized compounds [1], [2], [3] and [4] were dissolved in Dimethylslufoxide (DMSO) in three concentration $10 \mathrm{mg} \mathrm{mL}^{-1}, 1$ $\mathrm{mg} \mathrm{mL}^{-1}$ and $0.1 \mathrm{mg} \mathrm{mL}^{-1}$. These plates have been incubated by $\left(37^{\circ} \mathrm{C}\right)$ to $(24 \mathrm{hrs}$.). The inhibition zones give rises to the various compounds at the bacteria have been examined. For comparison, a standard antibiotic drug, gentamycin, was used as a standard for antimicrobial activity. 
<smiles>Cc1cc(=O)oc2cc(O)ccc12</smiles><smiles>CC(=O)CCl</smiles>

7-hydroxy-4-methyl-2H-chromen-2-one

1-chloropropan-2-one

4<smiles>CC(=O)COc1ccc2c(C)cc(=O)oc2c1</smiles>

4-methyl-7-(2-oxopropoxy)-2H-chromen-2-one (1)

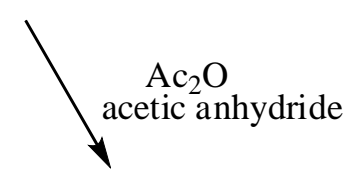

4-methyl-2-oxo-2 $H$-chromen-7-yl acetate (2)<smiles>Cc1cc(=O)oc2cc(OCc3cc(-c4ccc(N(C)C)cc4)c(C#N)c(=O)[nH]3)ccc12</smiles><smiles>Cc1cc(=O)oc2cc(OCc3cc(-c4ccc(N(C)C)cc4)c(C#N)c(=O)[nH]3)ccc12</smiles>

4-(4-(dimethylamino)phenyl)-6-((4-methyl-2-oxo- $2 H$-chromen-7-

yloxy)methyl)-2-oxo-1,2-dihydropyridine-3-carbonitrile (3)<smiles>CC(=O)Oc1ccc2c(C)cc(=O)oc2c1</smiles><smiles>Cc1cc(=O)oc2cc(Oc3cc(C4=C(Cl)CCOC4=O)c(C#N)c(=O)[nH]3)ccc12</smiles>

4-(4-chloro-2-oxo- $2 H$-chromen-3-yl)-6-(4-methyl-2-oxo- $2 H$-chromen-

7-yloxy)-2-oxo-1,2-dihydropyridine-3-carbonitrile

\section{Scheme (1)}




\section{Results and Discussion}

Compound (1) was prepared by substitution reaction between 7-hydroxy-4methyl-2H-chromen-2-one with chloroacetone in the presence of acetone as a solvent. FT-IR spectra from Compound (1) showed express absorption bands during (1735) $\mathrm{cm}^{-1}$ owing to $(\mathrm{C}=\mathrm{O})$ carbonyl group from ketone and the disappeared from absorption band at (3437) $\mathrm{cm}^{-1}$ for $(\mathrm{OH})$ group. The characteristic bands of compound (1) are shown in Table (1).

Compound (2) was synthesized through the reaction of 7-hydroxy-4-methyl-2Hchromen-2-one for acetic anhydride to give ester derivative; it was a tetrahedral nucleophilic substitution reaction. The characteristic bands of FTIR spectrum of compound (2) are shown in Table (4). The new 1,2-dihydropyridine-3-carbonitrile compound (3) was synthesized by the reaction of compound (1) with appropriate aldehyde (4-N, N-dimethylaminobenzaldehyde) and ethyl cyanoacetate in presence of ammonium acetate, show in scheme (1). Compound (3) was identified by FT-IR and several from them through ${ }^{1} \mathrm{HNMR}$ and ${ }^{13} \mathrm{C}-\mathrm{NMR}$ spectroscopy. The FTIR spectrum of compound (3) shows bands at the frequency of $\left(1650 \mathrm{~cm}^{-1}\right)$ owing to the carbonyl group from amide appears, the $\mathrm{NH}$ near (3220) $\mathrm{cm}^{-1}$. And the appearance from absorption band during (2208) $\mathrm{cm}^{-1}$ for $\mathrm{CN}$ group. The characteristic bands from compound (3) are shown in table (3).

Pyridinones derivatives (4) have been obtained by the reaction of substituted ketone with appropriate aldehyde in the presence of ethyl cyanoacetate and ammonium acetate.

The FTIR spectrum of compound (4) shows bands at the frequency of $\left(1656 \mathrm{~cm}^{-1}\right)$ owing to the carbonyl group from amide appears, the $\mathrm{NH}$ near (3105) $\mathrm{cm}^{-1}$. And the appearance from absorption band during (2208) $\mathrm{cm}^{-1}$ for $\mathrm{CN}$ group. The Characteristic bands from compound (4) are shown in table (3). The ${ }^{1}$ HNMR spectrum from compound (4) have been showed the following data: 2.2(s, $\left.3 \mathrm{H}, \quad \mathrm{CH}_{3}\right), \quad 4.4(\mathrm{~s}, \quad 1 \mathrm{H}, \mathrm{O}=\mathrm{C}-\mathrm{NH}), \quad 6.1$ $(\mathrm{s}, 1 \mathrm{H}, \mathrm{C}=\mathrm{CH}$ for pyridinone ring, $6.7(\mathrm{~s}$, $1 \mathrm{H}, \mathrm{C}=\mathrm{CH}$ for lactone ring $), 7.4-8.9(\mathrm{~m}, 7 \mathrm{H}$ owing to $\mathrm{Ar}-\mathrm{H}), 10.5(\mathrm{~s}, 1 \mathrm{H}$ owing to $\mathrm{OH}$ enol).

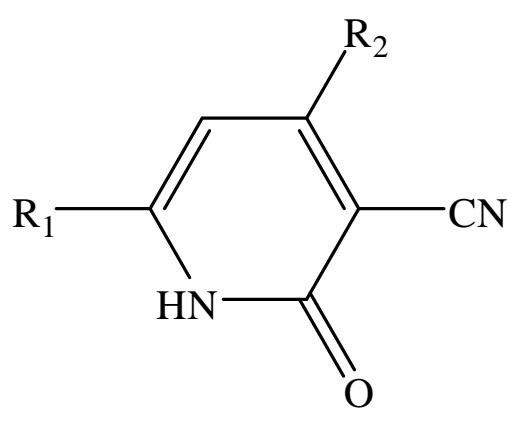

\section{Biological assay}

The antibacterial activity of the synthesized compounds (1-4) was evaluated against the bacterial strains Staphylococcus aureus and Streptococcus pyogenus (Gram +ve bacteria) and Escherichia coli and Klebsiella pneumniae (Gram -ve bacteria) by the disk diffusion method [19]. Standard drug (Gentamycin) was used at a concentration of 1 $\mathrm{mg} \mathrm{mL}^{-1}$ for comparisons.

The tested compounds were dissolved in Dimethylslufoxide (DMSO) to give a three solution of $10.00 \mathrm{mg} \mathrm{mL}^{-1}, 1.00 \mathrm{mg} \mathrm{mL}^{-1}$ and $0.10 \mathrm{mg} \mathrm{mL}^{-1}$. The inhibition zones have been measured at millimeters during the end from

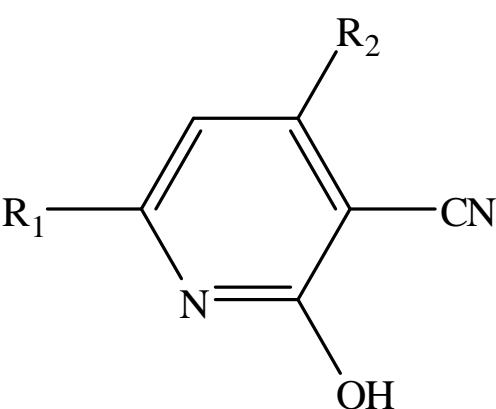

an incubation period from 48 hours during $37^{\circ} \mathrm{C}$. $N, N$-dimethylformamide (DMF) have been shown never inhibition zone. Test results have been shown at Table (4).

The data obtained in Table (4) indicate that the starting compound is biologically less active against gram +ve and gram-ve bacteria. The activity from Pyridinones are higher than the activity from the residue from the prepared compounds. The results of the preliminary screening test are listed in Table (4). From the data obtaind in Table (4), it is found that compound (3) has highest activity against Klebsiella pneumniae (gram-ve bacteria) at solution $10 \mathrm{mg} \mathrm{mL} \mathrm{L}^{-1}$, compound (3) is found 
to have the highest activity against Escherichia coli (gram-ve bacteria) at solution $1 \mathrm{mg} \mathrm{mL}^{-1}$. Compound (4) is found to have the highest activity against Streptococcus pyogenus (Gram +ve bacteria) at solution $1 \mathrm{mg} m L^{-1}$ and compound (4) is found to have the highest activity against Staphylococcus aureus (Gram +ve bacteria) at solution10 $\mathrm{mg} \mathrm{mL}^{-1}$, while the other solution compounds show either slight or no activity at all.

Table (1)

The FTIR spectrum of compound [1] in scheme (1).

\begin{tabular}{|c|c|c|c|c|c|c|}
\hline \multirow{2}{*}{$\begin{array}{c}\text { Comp. } \\
\text { No. }\end{array}$} & \multicolumn{6}{|c|}{ Characteristic bands of FT-IR spectrum $\left(\mathrm{cm}^{-}{ }^{1}\right)$} \\
\hline & $v \mathbf{C}=\mathbf{O}$ & $\begin{array}{c}\mathrm{UC}=\mathrm{O} \\
\text { Lactone }\end{array}$ & $\begin{array}{c}v \mathrm{C}=\mathrm{C} \\
\text { Ar. }\end{array}$ & uC-O-C & $\begin{array}{l}\text { uC-H } \\
\text { alph. } \\
\end{array}$ & $\begin{array}{c}\text { UC-H } \\
\text { Ar. }\end{array}$ \\
\hline [1] & 1735 & 1706 & $\begin{array}{l}1617 \\
1556\end{array}$ & 1135 & 2915,2845 & 3090 \\
\hline
\end{tabular}

Table (2)

The FTIR spectrum of compound [2] in scheme (1).

\begin{tabular}{|c|c|c|c|c|c|c|}
\hline \multirow[b]{2}{*}{ Comp. No. } & \multicolumn{6}{|c|}{ Characteristic bands of FT-IR spectrum $\left(\mathrm{cm}^{-}{ }^{1}\right)$} \\
\hline & $v \mathrm{C}=\mathbf{O}$ & $\begin{array}{c}\mathrm{UC}=\mathrm{O} \\
\text { Lactone }\end{array}$ & $\begin{array}{c}\mathrm{UC}=\mathrm{C} \\
\text { ar. }\end{array}$ & $\begin{array}{l}\text { uC-O } \\
\text { ester }\end{array}$ & $\begin{array}{l}\text { UC-H } \\
\text { alph. }\end{array}$ & Others \\
\hline$[2]$ & 1730 & 1707 & $\begin{array}{l}1505 \\
1565\end{array}$ & 1133 & $\begin{array}{l}2938, \\
2832\end{array}$ & $\begin{array}{c}\text { vC-H ar. } \\
3076\end{array}$ \\
\hline
\end{tabular}

Table (3)

Spectral data of compounds [3] and compound [4] in scheme (1).

\begin{tabular}{|c|c|c|c|c|c|}
\hline \multirow[b]{2}{*}{ Comp. No. } & \multicolumn{5}{|c|}{ Characteristic bands of FT-IR spectrum $\left(\mathrm{cm}^{-1}\right)$} \\
\hline & $\begin{array}{c}v \mathrm{C}=\mathrm{O} \\
\text { Lactone }\end{array}$ & uCN & $\begin{array}{l}v \mathrm{C}=\mathrm{O} \\
\text { amide }\end{array}$ & $v \mathrm{C}=\mathrm{C}$ & Others \\
\hline$[3]$ & 1703 & 2208 & 1650 & 1570 & $\begin{array}{c}\text { vC-H ar. } 3117 \\
\text { vC=N } 1612 \\
\text { vNH } 3220\end{array}$ \\
\hline [4] & 1739 & 2220 & 1656 & 1602 & $\begin{array}{c}\text { vC-H ar. } 2926, \\
\text { vC=N } 1618, \\
\text { vNH } 3105 .\end{array}$ \\
\hline
\end{tabular}

Table (4)

Antibacterial activities from several from the synthesized compounds.

\begin{tabular}{|c|c|c|c|c|c|c|c|c|c|c|c|c|}
\hline \multirow{3}{*}{$\begin{array}{l}\text { Comp. } \\
\text { No. }\end{array}$} & \multicolumn{6}{|c|}{ Gram positive } & \multicolumn{6}{|c|}{ Gram negative } \\
\hline & \multicolumn{3}{|c|}{ S. aureus } & \multicolumn{3}{|c|}{$\begin{array}{c}\text { Streptococcus } \\
\text { pyogenus }\end{array}$} & \multicolumn{3}{|c|}{ E. coli } & \multicolumn{3}{|c|}{$\begin{array}{c}\text { Klebsiella } \\
\text { pneumniae }\end{array}$} \\
\hline & $10^{-2}$ & $10^{-3}$ & $10^{-4}$ & $10^{-2}$ & $10^{-3}$ & $10^{-4}$ & $10^{-2}$ & $10^{-3}$ & $10^{-4}$ & $10^{-2}$ & $10^{-3}$ & $10^{-4}$ \\
\hline [1] & $\overline{-}$ & - & 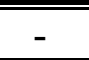 & 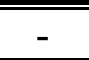 & $\overline{-}$ & - & - & - & - & 11 & 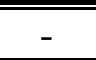 & - \\
\hline [2] & - & - & 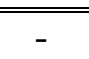 & - & - & - & 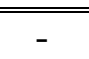 & - & - & - & - & - \\
\hline [3] & $\overline{-}$ & $\overline{-1}$ & 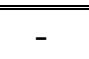 & - & $\overline{-1}$ & $\overline{-1}$ & 9 & 11 & $\overline{-1}$ & 19 & 15 & 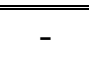 \\
\hline [4] & 10 & 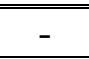 & - & - & 12 & 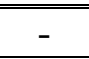 & 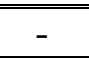 & - & - & - & - & - \\
\hline gentamycin & 20 & $\overline{15}$ & 10 & 20 & $\overline{15}$ & 10 & $\overline{15}$ & 10 & - & 15 & 10 & - \\
\hline
\end{tabular}

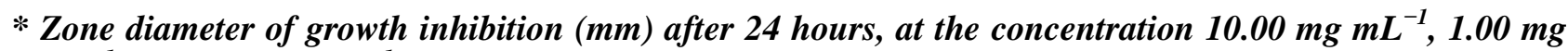
$m L^{-1}$ and $0.10 \mathrm{mg} \mathrm{mL}^{-1}$ in DMSO. 


\section{5- Conclusions}

In this work described the synthesis new 1,2-dihydropyridine-3-carbonitrile compounds derived from 4-methyl-7-(2-oxopropoxy)-2Hchromen-2-one and 4-methyl-2-oxo-2Hchromen-7-yl acetate. The preparation of 1,2dihydropyridine-3-carbonitrile derivatives, isolation, and characterization of a new compounds. The synthesized compounds were found to have the highest activity against Klebsiella pneumniae (Grame-ve bacteria) and Streptococcus pyogenus (Gram +ve bacteria).

\section{References}

[1] Venugopala K., Rashmi V., and Odhav B., "Review on natural coumarin lead compounds for their pharmacological activity”, Biomed. Res. Int., 1-14, 2013.

[2] Sandhu S., Bansal Y., Silakari O., and Bansal G., "Coumarin hybrids as novel therapeutic agents", Bioorg. Med. Chem., 22, 3806-3814, 2014.

[3] Choure R., and Pitre K., "Structural modification of coumarin for its increased anticoagulation potency", Can. J. Chem. Eng. Technol., 1, 7-15, 2010.

[4] Lad H., Giri R., and Brahmbhatt D., "An efficient synthesis of some new 3bipyridinyl substituted coumarins as potent antimicrobial agents". Chin. Chem. Lett., 24, 227-229, 2013.

[5] Jung K., Park Y., and Ryu J., "Scandium (III) Triflate - Catalyzed Coumarin Synthesis", Synth. Commun., 38(24), 43954406, 2008.

[6] Kostova I., "Synthetic and natural coumarins as cytotoxic agents", Curr. Med. Chem., 5, 29-46, 2005.

[7] Al-Amiery A., Kadhum A., and Mohamad A., "Antifungal activities of new coumarins", Molecules., 17, 5713-5723, 2012.

[8] Keri RS, Hosamani KM, Shingalapur RV, and Hugar $\mathrm{MH}$, "Analgesic, anti-pyretic and DNA cleavage studies of novel pyrimidine derivatives of coumarin moiety", Eur J Med Chem., 45, 2597-2605, 2010.

[9] Azari J. and Huxtable R. J., "Differential effects of amrinone on contractility and taurine influx in rat and guinea pig hearts", Eur. J.Pharmacol, 67, 347-353, 1980.

[10] Choi W., Houpis I. N., Charchil H. R. O., Molina A., Lynch J. E., Volante R. P., Reider P. J. and King A. O., "A practical synthesis of the 5-chloromethyl-furo[2,3b]pyridine pharmacophore", Tetrahedron, 36(26), 4571-4574, 1995.

[11] Henry G.D., "De novo synthesis of substituted pyridines", Tetrahedron, 60(29), 6043-6061, 2004.

[12] Li A.H., Moro S., Forsyth N., Melman N., Ji X. D., Jacobsen K.A., "Synthesis, CoMFA Analysis, and Receptor Docking of 3,5-Diacyl-2,4-Dialkylpyridine Derivatives as Selective A3 Adenosine Receptor Antagonists", J. Med. Chem., 42, 706-721, 1999.

[13] Son J.K., Zhao L.X., Basnet A., Thapa P., Karki R., Na Y., Jahng Y., Jeong T.C., Jeong B.S., Lee C.S., and Lee E.S., "Synthesis of 2,6-diaryl-substituted pyridines and their antitumor activities", Eur. J. Med. Chem., 43(4), 675-682, 2008.

[14] Hammam A.G., Abdel Hafez N.A., Midura W.H., and Mikolajczyk M.Z., "Chemistry of Seven-Membered Heterocycles, VI. Synthesis of Novel Bicyclic Heterocyclic Compounds as Potential Anticancer and Anti-HIV Agents", Z. Naturforsch., 55(5), 417-424, 2000.

[15] Abo-Ghalia M., Abdulla M.M.Z., and Amr A.E., "Synthesis of Some New (NaDipicolinoyl)-bis-L-leucyl-DL-norvalyl Linear tetra and Cyclic octa Bridged Peptides as New Antiinflammatory Agents", Z. Naturforsch., 58(9), 903-912, 2003.

[16] Ibraheem H., AL-Bayati R. and Hameed S., "Synthesis and Characterization of New heterocycles compounds derived from coumarin", Al- Mustansiriyah J. Sci., 27(3), 29-35, 2016.

[17] Beheshtia Y., Khorshidi M., Heravi M. and Baghernejad B., "DABCO as an efficient catalyst for the synthesis of 3cyano-2 $(1 \mathrm{H})$-pyridinones and their 2-imino analogues", Eur. J.Chem., 1 (3), 232- 235, 2010.

[18] Muratovic S., Duric K., Veljovic E., Osmanovic A., Softic D. and Zavrsnik D., "Synthesis of biscoumarin derivatives as antimicrobial agents", Asian J Pharm Clin Res, 6(3), 132-134, 2013.

[19] Bonev B., Hooper J., and Parisot J., "Principles of assessing bacterial susceptibility to antibiotics using the agar diffusion method", The Journal of antimicrobial chemotherapy, 61 (6), 12951301, 2008. 